\title{
Kontak Bahasa antara Komunitas Tutur Bahasa Bugis dengan Komunitas Tutur Bahasa Sasak di Pulau Lombok
}

\author{
Desi Rachmawati*)
}

\begin{abstract}
Abstrak
Penelitian ini merupakan salah satu kajian sosiolinguistik, yang melibatkan unsur sosial dan unsur kebahasaan yang terjadi pada masyarakat bilingual dan multilingual dengan cara melakukan adaptasi sosial dan adaptasi linguistik. Adaptasi linguistik yang dilakukan oleh komunitas tutur bahasa Bugis terhadap bahasa Sasak hanya ditemukan dalam bentuk serapan fonologi, dan serapan leksikon. Kecenderungan dari adaptasi linguistik yang terkait dengan kuat-kurangnya pengaruh bahasa Sasak terhadap bahasa Bugis pada enklave Haji dan enklave Pelangan berkategori dominan. Sedangkan pengaruh bahasa Bugis terhadap bahasa Sasak pada enklave Haji dan enklave Pelangan termasuk dalam kreteria kurang. Penggunaan bahasa Indonesia dalam masyarakat tutur bahasa Bugis pada enklave Haji dan enklave Pelangan terjadi akibat adanya alih kode dan campur kode. Terjadinya pengaruh bahasa yang dominan dan bervariasi pada kedua enklave di atas disebabkan oleh beberapa faktor antara lain geografi, sosial (ekonomi, pendidikan, kebutuhan, usia) dan budaya,
\end{abstract}

Kata kunci: interaksi, adaptasi sosial, dan adaptasi bahasa

\section{Pengantar}

Keberagaman suku bangsa di Indonesia selain terefleksi dari banyaknya budaya dan adat istiadat juga terrefleksi dari banyaknya bahasa yang dituturkan oleh suku bangsa tersebut, seperti halnya suku Bugis, Bajo dan Selayar sebagai suku di Provinsi Sulawesi yang mayoritas tinggal di pinggir-pinggir pantai dan bermata pencaharian sebagai nelayan. Oleh karena itu, masyarakat Bugis, Bajo dan Selayar tidak jarang kita jumpai menempati daerah-daerah pinggir pantai pada

\footnotetext{
*) Sarjana Pendidikan, Pembantu Pimpinan pada Kantor Bahasa Prov. NTB
} 
setiap Pulau di Indonesia. Salah satu Pulau yang ditempati oleh etnik Bajo, Bugis, dan Selayar adalah Pulau Lombok.

Sementara itu, sejalan dengan keberadaan komunitas Bugis sebagai komunitas pendatang di Pulau Lombok yang hidup di tengah/dikelilingi oleh komunitas Sasak sebagai komunitas setempat dan komunitas pendatang lainnya membawa fenomena kemajemukan. Adapun fenomena kemajemukan itu dapat terlihat dari kehidupan sosial dan kemasyarakatan. Hal tersebut dipacu dan ditopang oleh kenyataan selalu bertemu dan berinteraksinya warga masyarakat suku Sasak dan Bugis dalam wahana kegiatan sehari-hari sehingga banyak terdapat individu pada suku Bugis yang memiliki dan menguasai banyak bahasa (multilingual) atau sedikitnya dua bahasa (bilingual), begitu juga sebaliknya.

Dalam hubungannya dengan kesamaan budaya termasuk bahasa, suatu masyarakat yang berasal dari latar belakang bahasa ibu yang berbeda pada awal proses komunikasinya cenderung menggunakan bahasa Indonesia sebagai bahasa pengantar. Kontak antara dua komunitas yang berbeda tersebut menuntut adanya adaptasi sosial dimana tiap komunitas saling menyesuaikan. Seperti pernyataan yang dikemukakan oleh Mahsun (2006:1) bahwa adaptasi sosial dapat dimaknai sebagai kontak sosial, yang melibatkan dua kelompok komunitas yang memiliki perbedaan budaya atau ras melakukan penyesuaiaan satu sama lain. Interaksi atau kontak antara dua komunitas yang berbeda menuntut adanya adaptasi sosial dari salah satu atau keduanya dari dua komunitas yang berinteraksi tersebut yang dapat dilihat melalui adanya penyesuaian unsur-unsur kebahasaan antara dua komunitas yang berinteraksi daan saling mengadopsi ciri-ciri kebahasaan 
tertentu sehingga bahasa yang digunakan menjadi lebih serupa, mirip atau sama satu sama lain.

Oleh karena itu, penelitian ini akan mencoba mendeskripsikan wujud pola adaptasi linguistik yang terjadi pada setiap daerah kantong Bugis yang telah dijadikan sasaran dalam penelitian ini serta mengetahui segmen sosial mana yang lebih dominan untuk melakukan adaptasi linguistik yang berwujud serapan yang terjadi pada setiap daerah kantong Bugis yang ada di Pulau Lombok.

Untuk analisis data dengan tujuan memperoleh gambaran ihwal bentuk/pola adaptasi linguistik akan dengan menggunakan metode padan: teknik hubung-banding menyamakan (HBS) dan teknik hubung-banding membedakan (HBB). Secara operasional, metode dan teknik ini digunakan dengan maksud menghubung-bandingkan antara bentukbentuk yang menjadi realisasi makna tertentu dalam dua bahasa yang digunakan oleh masing-masing komunitas tutur yang menjadi penelaahan. Tujuan dari metode dengan teknik ini adalah untuk memilah unsur mana yang merupakan unsur asli dan mana yang merupakan hasil adaptasi linguistik, baik yang berupa adaptasi fonologis maupun yang berupa serapan leksikal atau gramatikal yang terdapat dalam salah satu dari kedua bahasa yang komunitas tuturnya melakukan kontak tersebut.

Metode analisis data dengan kuantitatif digunakan untuk menjawab masalah yang berhubungan dengan masyarakat tutur yang mendominasi melakukan adaptasi linguistik. 


\section{Pembahasan}

\subsection{Pengaruh Bahasa Sasak terhadap Bahasa Bugis Setempat}

\subsubsection{Pengaruh Bahasa Sasak terhadap Bahasa Bugis Haji}

Bahasa Sasak sebagai bahasa komunitas yang ada wilayah Pulau Lombok memiliki peranan yang sangat besar dalam memengaruhi keberadaan bahasa Bugis-Haji dan Bugis-Pelangan sebagai bahasa komunitas pendatang. Pengaruh bahasa Sasak ini memiliki bentuk, yakni serapan. Berdasarkan data yang diperoleh dari keseluruhan sampel penelitian yang berlokasi Bugis-Haji di Lombok Timur, diperoleh gambaran bahwa adaptasi linguistik yang dilakukan komunitas tutur Bugis terhadap bahasa Sasak hanya ditemukan dalam bentuk serapan fonologi dan serapan leksikon. Adaptasi linguistik yang berupa serapan bunyi sangat sedikit diketemukan pada komunitas tutur bahasa Bugis, dari sekitar 61 kata yang berupa serapan hanya 4 buah kata yang berupa serapan fonologis seperti pada kata makna 'teriak' dalam bahasa Bugis direalisasikan dalam bentuk gora, sedangkan dalam bahasa Sasak makna tersebut direalisasikan dalam bentuk ñurak. Akan tetapi, karena adanya interaksi sosial antardua komunitas mengakibatkan komunitas tutur bahasa Bugis-Haji segmen sosial tua dan muda menyerap unsur bahasa sama dengan penyesuaian ejaan, dalam hal ini berupa adanya upaya menghilangkan fonem /g/ menjadi /ñ / dan /y/ pada posisi awal. Sehingga komunitas tutur bahasa Bugis-Haji segemen sosial muda dan tua merealisasikan makna tersebut ke dalam bentuk ñora. Di samping itu, segmen sosial tua pada komunitas tutur bahasa Bugis-Haji sampai saat ini masih menggunakan bentuk realisasi gora untuk makna tersebut. Data ini menunjukkan bahwa ada kemiripan antara data serapan dengan data 
realisasi makna ñurak yang dimiliki oleh penutur bahasa Sasak pada umumnya.

Sementara itu adaptasi linguistik yang berupa serapan leksikon merupakan bentuk yang lebih banyak dilakukan. Pada enklave BugisHaji, terdapat sekitar 61 buah kata serapan. Dari 61 buah kata tersebut, terdapat sekitar 57 buah kata serapan leksikon yang diserap oleh komunitas tutur bahasa Bugis-Haji muda terhadap bahasa Sasak, kemudian sekitar 19 buah kata serapan leksikon yang diserap komunitas tutur bahasa Bugis-Haji tua terhadap bahasa Sasak. Adaptasi linguistik yang mereka gunakan berupa serapan leksikon yang berasal dari kata yang merupakan bahasa Sasak Standar (yang umum digunakan), disamping unsur serapan yang berasal dari bahasa Sasak varian setempat (bahasa Sasak yang secara geografis berdekatan dengan lokasi bahasa Bugis-Haji. Adapun contoh serapan leksikon seperti pada kata toak 'bahu'. Bentuk tersebut diserap secara utuh oleh penutur bahasa Bugis tua dan muda dari bahasa Sasak, sedangkan dalam bahasa Bugis makna tersebut direalisasikan dengan bentuk salajka.

\subsubsection{Pengaruh Bahasa Lain terhadap Bahasa Bugis-Haji}

Adaptasi linguistik antara dua atau lebih komunitas yang berbeda bahasa akan muncul suatu bahasa yang memiliki pengaruh yang lebih dominan terhadap bahasa yang lainnya. Bahasa tersebut dapat berupa bahasa mitra kontak atau dapat juga berupa bahasa lain (selain bahasa mitra kontak), yang pemakaiannya cenderung lebih luas, seperti bahasa nasional. Selanjutnya pengaruh yang dominan tersebut dapat saja kepada setiap bahasa yang berkontak atau hanya berpengaruh kepada salah satu 
bahasa saja. Pengaruh bahasa lain dalam hal ini adalah bahasa Indonesia yang berupa serapan fonologi dan leksikon. Sementara itu serapan karena pengaruh bahasa daerah lain ditemukan dalam bentuk serapan leksikon secara utuh.

Pengaruh bahasa Indonesia hanya satu dijumpai, yaitu berupa serapan fonologi pada komunitas tutur bahasa Bugis-Haji, adapun serapan tersebut berupa perubahan fonem /e/ menjadi /a/ pada posisi awal setelah konsonan, perubahan tersebut dijumpai pada bentuk sepatu dalam bahasa Indonesia berubah menjadi sapatu (bentuk yang digunakan komunitas tutur bahasa Bugis-Haji muda dan tua). Sementara itu adaptasi linguistik dalam bentuk serapan leksikon karena pengaruh bahasa Indonesia lebih banyak dilakukan, adapun serapan tersebut berjumlah 34 buah kata serapan leksikon yang terdiri atas 34 buah kata serapan yang dilakukan oleh segmen sosial muda komunitas tutur bahasa Bugis-Haji, 31 buah kata serapan oleh segmen usia tua komunitas tutur bahasa BugisHaji, adapun contohnya terdapat pada kata bulu mata diserap secara utuh oleh penutur bahasa Bugis-Haji tua dan muda dari bahasa Indonesia, dalam bahasa Bugis makna tersebut juga diserap dari bahasa Indonesia.

Selanjutnya adaptasi linguistik karena pengaruh bahasa daerah lain hanya ditemukan dalam bentuk serapan leksikon secara utuh. Adapun serapan tersebut berjumlah 31 buah kata serapan leksikon yang terdiri atas 27 buah kata serapan yang dilakukan oleh segmen sosial muda komunitas tutur bahasa Bugis-Haji, 30 buah kata diserap oleh segmen sosial tua komunitas tutur bahasa Bugis-Haji dapat dilihat pada kata majailiy 'lirik' bentuk ini diserap utuh oleh komunitas tutur bahasa Bugis-Haji muda dan tua dari bahasa daerah lain. Adapun wujud realisasi untuk makna tersebut dalam bahasa Bugis adalah malirik yang diserap 
dari bahasa Indonesia.

\subsubsection{Pengaruh Bahasa Sasak terhadap Bahasa Bugis-Pelangan}

Berdasarkan data yang diperoleh dari keseluruhan sampel penelitian yang berlokasi Bugis-Pelangan di Lombok Barat, diperoleh gambaran bahwa adaptasi linguistik yang dilakukan komunitas tutur Bugis terhadap bahasa Sasak hanya ditemukan dalam bentuk serapan fonologi dan serapan leksikon.

Adaptasi linguistik yang berupa serapan bunyi merupakan bentuk yang sangat sedikit ditemukan, ada sekitar tiga buah kata yang berupa serapan fonologi. contoh serapan tersebut dapat terlihat pada makna 'teriak' dalam bahasa Bugis direalisasikan dalam bentuk gora, sedangkan dalam bahasa Sasak makna tersebut direalisasikan dalam bentuk ñurak. Akan tetapi, karena adanya interaksi sosial antar dua komunitas tersebut maka mengakibatkan komunitas tutur bahasa BugisPelangi segmen sosial muda dan tua menyerap unsur bahasa sama dengan penyesuaian ejaan, dalam hal ini berupa adanya upaya perubahan fonem /g/ menjadi / $\tilde{n} /$ dan $/ \mathrm{y} /$ pada posisi awal. Sehingga komunitas tutur bahasa Bugis-Pelangan segmen sosial muda dan tua merealisasikan makna tersebut ke dalam bentuk ñora dan yora.

Sementara itu adaptasi linguistik yang berupa serapan leksikon merupakan bentuk yang lebih banyak dilakukan. Selanjutnya bahasa yang paling banyak melakukan adaptasi adalah Bugis-Pelangan, yaitu sekitar 34 buah kata. Dari 34 buah kata tersebut, terdapat sekitar 31 buah kata serapan yang berupa serapan leksikon dan seluruhnya diserap oleh komunitas tutur bahasa Bugis muda terhadap bahasa Sasak, kemudian 
sekitar 14 buah kata serapan leksikon diserap komunitas tutur bahasa Bugis tua terhadap bahasa Sasak. Adaptasi linguistik yang mereka gunakan berupa serapan leksikon yang berasal dari kata yang merupakan bahasa Sasak standar (yang umum digunakan), di samping unsur serapan yang berasal dari bahasa Sasak varian setempat (bahasa Sasak yang secara geografis berdekatan dengan lokasi bahasa Bugis-Pelangan, contohnya dapat dilihat pada kata toak 'bahu' bentuk tersebut diserap secara utuh oleh penutur bahasa Bugis tua dan muda dari bahasa Sasak, sedangkan dalam bahasa Bugis makna tersebut direalisasikan dengan bentuk salayka.

\subsubsection{Pengaruh Bahasa Lain terhadap Bahasa Bugis-Pelangan}

Adaptasi linguistik antar dua atau lebih komunitas yang berbeda bahasa akan muncul suatu bahasa yang memiliki pengaruh yang lebih dominan terhadap bahasa yang lainnya. Bahasa tersebut dapat berupa bahasa mitra kontak atau dapat juga berupa bahasa lain (selain bahasa mitra kontak), yang pemakaiannya cenderung lebih luas, seperti bahasa nasional. Selanjutnya pengaruh yang dominan tersebut dapat saja kepada setiap bahasa yang berkontak atau hanya berpengaruh kepada salah satu bahasa saja.

Sementara itu dari data-data yang telah diidentifikasikan dijumpai adanya pengaruh bahasa lain dalam hal ini, yaitu pengaruh bahasa Indonesia dan pengaruh bahasa daerah lain. Pengaruh bahasa Indonesia dapat dijumpai berupa serapan fonologi, adapun serapan tersebut berupa perubahan fonem /e/ menjadi /a/ pada posisi awal setelah konsonan, perubahan tersebut dijumpai pada bentuk sepatu dalam bahasa Indonesia 
berubah menjadi sapatu (bentuk yang digunakan komunitas tutur bahasa Bugis-Pelangan muda dan tua).

Selanjutnya bentuk serapan leksikon karena pengaruh bahasa Indonesia lebih banyak dilakukan, adapun serapan tersebut berjumlah 62 buah kata serapan yang diserap oleh komunitas tutur Bugis-Pelangan, yang terdiri dari 62 buah kata serapan oleh segmen usia muda komunitas tutur Bugis-Pelangan dan 34 buah kata serapan yang diserap oleh segmen usia tua komunitas tutur bahasa Bugis-Pelangan. Untuk lebih rinci berikut ini akan dipaparkan beberapa contoh kata yang berupa serapan leksikon yang diserap oleh tiap komunitas tutur bahasa Bugis-Pelangan karena pengaruh bahasa Indonesia, contoh serapan tersebut dapat dilihat pada kata manjur diserap secara utuh oleh penutur bahasa BugisPelangan muda dari bahasa Indonesia, penutur bahasa Bugis tua masih memakai bentuk realisasi dalam bahasa Bugis untuk makna tersebut yaitu mujarrabe.

Adaptasi linguistik karena pengaruh bahasa daerah lain hanya ditemukan dalam bentuk serapan leksikon secara utuh, berjumlah 38 buah kata serapan yang terdiri dari 26 buah kata diserapan oleh segmen sosial muda komunitas tutur Bugis-Pelangan, dan 39 buah kata serapan oleh komunitas tutur Sasak-Pelangan. Wujud serapan tersebut dapat dilihat pada kata hEnay 'benang jahit' bentuk ini diserap utuh oleh komunitas tutur bahasa Bugis-Pelangan muda dan tua dari bahasa daerah lain. Adapun wujud realisasi untuk makna tersebut dalam bahasa Bugis adalah pittek.

\subsection{Pengaruh Bahasa Bugis terhadap Bahasa Sasak Setempat}




\subsubsection{Pengaruh Bahasa Bugis terhadap Bahasa Sasak-Haji}

Berdasarkan data yang diperoleh dari keseluruhan sampel penelitian yang berlokasi Bugis-Haji di Lombok Timur diperoleh gambaran bahwa adaptasi linguistik yang dilakukan komunitas tutur Sasak terhadap bahasa Bugis hanya ditemukan dalam bentuk serapan fonologi.

Serapan fonologi yang diketemukan tidak hanya terjadi pada komunitas tutur bahasa Bugis, tetapi begitu pula sebaliknya komunitas tutur bahasa Sasak varian setempat pun mengalami adaptasi linguistik yang berbentuk serapan bunyi pada makna 'teriak'. Hal ini disebabkan adanya interaksi sosial antar dua komunitas tersebut maka mengakibatkan komunitas tutur bahasa Sasak-Haji segmen sosial muda dan tua menyerap unsur bahasa sama dengan penyesuaian ejaan, adapun perubahan bunyi yang dimaksud terjadi pada fonem / $\mathrm{u} /$ berubah menjadi fonem /o/ pada posisi tengah dan menghilangkan fonem / $/$ / pada posisi akhir selain itu karena adanya interaksi sosial antar dua komunitas mengakibatkan komunitas tutur bahasa Sasak-Haji segmen sosial muda dan tua pada komunitas tutur bahasa Sasak menyerap unsur bahasa sama dengan penyesuaian ejaan dalam hal ini berupa adanya upaya menghilangkan fonem / $\tilde{n} /$ menjadi /y/ pada posisi awal. Pada bahasa Bugis makna 'teriak' direalisasikan dalam bentuk 'gora' dan pada makna 'teriak' pada bahasa Sasak direalisasikan dalam bentuk ñurak, sedangkan penutur Sasak varian setempat merealisasikan makna tersebut ke dalam bentuk ñora dan yora.

\subsubsection{Pengaruh Bahasa Lain terhadap Bahasa Sasak-Haji}


Banyaknya komunitas etnis pendatang yang menetap di sekitar wilayah komunitas tutur Sasak-Haji dimungkinkan menyebabkan munculnya adaptasi linguistik dalam bentuk serapan yang dapat dipengaruhi oleh bahasa mitra kontak atau dipengaruhi oleh bahasa lain (selain bahasa mitra kontak). Adapun bahasa lain yang dimaksud adalah bahasa Indonesia atau bahasa daerah lain.

Pengaruh bahasa Indonesia terhadap bahasa Sasak hanya ditemukan dalam bentuk serapan leksikon yang berjumlah 14 buah untuk komunnitas tutur bahasa Sasak-Haji. Dari jumlah serapan tersebut seluruhnya diserap oleh komunitas tutur bahasa Sasak-Haji muda dan tua, seperti pada makna 'alis, siku dan kasar' diserap secara utuh oleh komunitas tutur bahasa Sasak-Haji segmen sosial tua dan muda. Selanjutnya adaptasi linguistik karena pengaruh bahasa daerah lain hanya ditemukan dalam bentuk serapan leksikon secara utuh dan dijumpai pada enklave Sasak-Haji Adapun serapan tersebut terdapat pada makna 'lama' dalam bahasa Sasak direalisasikan dalam bentuk yoneq sementara komunitas tutur bahasa Sasak segmen usia muda dan tua varian setempat menggunakan bentuk suwe sebagai alternatif ketiga untuk makna tersebut. Selanjutnya makna 'lambat' dalam bahasa Sasak direalisasikan dalam bentuk səkat dan tolat, sementara komunitas tutur bahasa Sasak segemen usia muda dan tua varian setempat menggunakan 'alon' sebagi alternatif ketiga untuk makna tersebut.

\subsubsection{Pengaruh Bahasa Bugis terhadap Bahasa Sasak-Pelangan}

Berdasarkan data yang diperoleh dari keseluruhan sampel penelitian yang berlokasi Bugis-Pelangan di Lombok Barat diperoleh 
gambaran bahwa adaptasi linguistik yang dilakukan komunitas tutur Sasak terhadap bahasa Bugis ditemukan dalam bentuk serapan fonologi dan leksikon.

Serapan fonologi dengan adanya penyerapan unsur bahasa sama dengan penyesuaian ejaan yang diketemukan hanya satu buah kata, adapun serapan yang terjadi pada komunitas tutur bahasa Sasak terhadap makna 'teriak', yaitu adanya perubahan bunyi pada fonem /u/ berubah menjadi fonem /o/ pada posisi tengah dan hilangnya fonem / $/$ pada posisi akhir. Pada bahasa Bugis makna 'teriak' direalisasikan dalam bentuk 'gora' dan pada bahasa Sasak direalisasikan dalam bentuk ñurak. Sementara itu penutur Sasak segmen sosial muda setempat merealisasikan makna tersebut ke dalam bentuk ñorak. Sementara itu komunitas tutur bahasa Sasak-Pelangan tua dan muda menyerap 2 buah kata yang berbentuk leksikon dari bahasa Bugis, yaitu pada makna 'tari' dalam bahasa Sasak direalisasikan dalam bentuk igəl dan yibəy karena adanya interaksi sosial antara dua komunitas tersebut, maka mengakibatkan komunitas tutur bahasa Sasak-Pelangan segmen sosial tua dan muda menyerap kosakata bahasa Bugis, yaitu jogek untuk makna yang sama.

\subsubsection{Pengaruh Bahasa Lain terhadap Bahasa Sasak-Pelangan}

Banyaknya komunitas etnis pendatang yang menetap di sekitar wilayah komunitas tutur Sasak-Pelangan dimungkinkan menyebabkan munculnya adaptasi linguistik dalam bentuk serapan yang dapat dipengaruhi oleh bahasa mitra kontak atau dipengaruhi oleh bahasa lain (selain bahasa mitra kontak). Adapun bahasa lain yang dimaksud adalah bahasa Indonesia atau bahasa daerah lain. 
Adaptasi linguistik karena pengaruh bahasa Indonesia hanya ditemukan dalam bentuk serapan leksikon secara utuh berjumlah sekitar 20 buah kata pada komunitas tutur bahasa Sasak-Pelangan, seperti pada makna 'jari manis, siku dan boros' diserap secara utuh oleh komunitas tutur bahasa Sasak-Pelangan segmen sosial tua dan muda.

\subsection{Adaptasi Linguistik yang Berbentuk Alih Kode}

Alih kode merupakan salah satu fenomena kebahasaan yang terjadi akibat kontak antara dua komunitas yang berbeda bahasa. Selanjutnya dalam komunitas yang multietnis, alih kode merupakan sebuah kebutuhan, baik kebutuhan yang didorong oleh kepentingan pribadi, golongan maupun didorong oleh kepentingan sosial yang lain. Adapun dari data-data yang terjaring, data yang menunjukan adanya adaptasi linguistik dalam bentuk alih kode yang terjadi akibat kontak yang terjadi antara komunitas tutur bahasa Bugis dan Sasak dapat terlihat pada saat komunitas Bugis berkomunikasi dengan sesama etnis maupun ketika berkomunikasi dengan etnis Sasak. Selanjutnya sebagai etnis minoritas secara sosial dan linguistik etnis Bugis sangat adaptif atau konvergen karena hampir keseluruhan anggota etnis adalah multilingual (BBG, BSas, dan BI). Keharusan menguasai BSas oleh beberapa informan karena sejumlah alasan, yaitu untuk memudahkan interaksi dan adaptasi secara sosial budaya dan ekonomi, mengantisipasi kelicikan dan penipuan, menghormati dan menghargai etnis Sasak sebagai etnis mayoritas, dan dipelajari untuk menambah pengetahuan. Alih kode yang dilakukan oleh etnis Bugis tidak hanya ke BSas, tetapi juga ke bahasa Indoensia (BI). Alih kode ke BI ini biasa dilakukan oleh etnis Bugis yang 
baru datang dari Sulawesi Selatan ketika berinteraksi dengan etnis Sasak atau siapa saja yang dilihat bukan etnis Bugis dan atau tidak mengarti bahasa Bugis. Sementara alih kode ke BI oleh etnis Bugis yang sudah lama menetap di Lombok dan dapat berbahasa Sasak biasanya dilakukan pada kondisi-kondisi sosial tertentu, seperti ketika melakukan pertemuan formal dengan etnis lain, bertemu dengan orang yang belum jelas keetnisannya, atau dengan etnis lain yang datang dengan urusan penting, mendesak, atau dengan etnis lain yang memeliki kelas sosial tinggi dan atau tidak akrab. Sementara itu menurut informan ketika etnis Bugis sedang bercakap-cakap dengan sesama etnis, tiba-tiba datang etnis Sasak. Pada kondisi ini etnis Bugis yang bercakap-cakap akan beralih kode ke BSas untuk menyambut, menegur, atau sekadar menyapa etnis Sasak tersebut.

\subsection{Kecenderungan Masing-Masing Enklave yang Melakukan} Adaptasi Linguistik

Kecenderungan dari adaptasi linguistik yang dimaksud adalah terkait dengan dominan dan kurang dominannya pengaruh bahasa Sasak terhadap bahasa Bugis pada enklave Bugis-Haji berkategori dominan yaitu sebesar 61,6\%, enklave Bugis-Pelangan berkategori sedang sebesar 38,3\%. Selanjutnya pengaruh bahasa Bugis terhadap bahasa Sasak pada enklave Sasak-Haji berkategori sedang sebesar 33,3 \%, enklave Sasak-Pelangan berkategori dominan sebesar 66,6\%.

\subsubsection{Kecenderungan Segmen Sosial Komunitas Tutur Bahasa} Bugis yang Melakukan Adaptasi Linguistik Pada MasingMasing Enklave 
Pada segmen sosial komunitas tutur Bugis-Haji maupun komunitas tutur Bugis-Pelangan memiliki kecenderungan melakukan adaptasi linguistik, adaptasi linguistik yang dimaksud terkait dengan kuat atau kurangnya pengaruh bahasa Sasak terhadap bahasa Bugis pada enklave Bugis-Haji segmen sosial muda berkategori dominan sebesar $74,0 \%$, segmen sosial tua berkategori kurang sebesar $25,9 \%$. Sementara itu pada enklave Bugis-Pelangan segmen sosial muda berkategori dominan sebesar 6,6\%, segmen sosial tua berkategori sedang sebesar $33,3 \%$. Selanjutnya pengaruh bahasa Bugis terhadap bahasa Sasak pada enklave Sasak-Haji segemen sosial muda dan tua berkategori dominan sebesar 50 \%. Pada enklave Sasak-Pelangan segmen sosial muda berkategori dominan sebesar $66,6 \%$, sementara itu segmen sosial tua berkategori sedang sebesar 33,3\%.

\subsection{Faktor-Faktor Yang Memengaruhi Kecenderungan Suatu Segmen Melakukan Adaptasi Linguistik}

Pada bagian ini, akan dibahas faktor-faktor yang memengaruhi terjadinya kecenderungan adaptasi linguistik berdasarkan hasil perhitungan daerah pengamatan dan segmen sosial pada setiap daerah pengamatan. Perhitungan adaptasi linguistik ini dilakukan berdasarkan pengaruh bahasa Sasak terhadap bahasa Bugis, pengaruh bahasa Indonesia terhadap bahasa Bugis, pengaruh bahasa Bugis terhadap bahasa Sasak, dan pengaruh bahasa Indonesia terhadap bahasa Sasak dengan kreteria dominan, sedang, dan kurang. Adapun pengaruh bahasa Indonesia terhadap bahasa Bugis maupun bahasa Sasak terjadi akibat adanya alih kode dan campur kode yang terjadi pada masyarakat tutur. 
Apabila penutur bahasa Bugis atau bahasa Sasak dalam berkomunikasi tidak seutuhnya faham akan bahasa yang mereka gunakan, secara otomatis mereka akan beralih kode atau bercampur kode dengan bahasa Indonesia.

Dari hasil perhitungan persentase di atas, diperoleh hasil bahwa: (1) berdasarkan enklave yang mendapat pengaruh bahasa Sasak lebih dominan adalah enklave Bugis Haji; sedangkan (2) berdasarkan segmen sosial yang mendapat pengaruh lebih dominan adalah segmen sosial muda, dan hal tersebut diketemukan di kedua enklave baik Bugis Haji maupun Bugis Pelangan. Sedangkan segmen sosial tua mendapatkan pengaruh yang bervariasi.

Terjadinya pengaruh bahasa yang dominan dan bervariasi ini disebabkan berbagai faktor antara lain geografi, sosial (ekonomi, pendidikan, dan usia) dan budaya. Untuk lebih jelasnya berikut ini akan dibahas satu per satu.

\section{A. Faktor Geografis}

Tidak dapat dipungkiri bahwa letak suatu wilayah sangat mempengaruhi adanya adaptasi linguistik. Di mana daerah yang mempunyai letak cukup stategis sebagai jalur perhubungan dan pemerintahan akan mudah terpengaruh oleh bahasa lain dibandingkan dengan daerah yang kurang strategis. Di samping itu letak geografis suatu wilayah juga disertai pula dengan tingkat kelancaran untuk mencapai wilayah tersebut setidaknya akan berpengaruh juga pada bahasa yang digunakan untuk berkomunikasi. Suatu daerah yang terbuka akan lebih banyak mendapat pengaruh dari bahasa lain. Enklave Bugis Haji yang terletak di ujung timur Pulau Lombok merupakan daerah yang 
terbuka karena sebagai lintasan wilayah dari berbagai daerah sehingga akan lebih banyak menerima pengaruh begitu juga sama halnya dengan enklave Bugis Pelangan yang terletak di ujung barat Pulau Lombok.

\section{B. Faktor sosial dan budaya}

Dalam keseharian, faktor sosial dan budaya mendominasi kehidupan. Semua tindakan didasarkan pada norma- norma yang dianut. Adapun faktor sosial dapat dilihat dari beberapa aspek antara lain (1) aspek sosial ekonomi pada masing-masing enklave memiliki mata pencaharian yang bervariatif, penduduk di enklave Labuhan Haji lebih bervariatif dibandingkan dengan mata pencaharian penduduk di enklave Pelangan. Mayoritas penduduk di enklave Pelangan adalah petani dan hanya sebagian kecil yang berprofesi sebagai pegawai dan pedagang. Pada umumnya petani tidak memiliki mobilitas untuk bepergian yang tinggi. Dari data hasil wawancara rata-rata mereka bepergian ke luar wilayah hanya berkisar 2 sampai 3 kali dalam setahun. Alasan kepergian mereka hanya untuk memenuhi kebutuhan untuk pertanian dan mengunjungi keluarga. Dibandingkan dengan penduduk enklave Labuhan Haji yang mata pencahariannya lebih variatif dan didukung pula oleh mobilitas penduduk yang tinggi maka enklave ini melakukan adaptasi yang lebih tinggi dibandingkan dengan enklave Pelangan. Mudahnya transportasi dan tingkat kebutuhan kerja memungkinkan untuk sering bepergian. Komposisi mata pencaharian penduduk, seperti pegawai, pedagang dan wiraswasta merupakan mata pencaharian yang memiliki mobiltas and tingkat interaksi yang tinggi untuk beradaptasi, (2) aspek sosial pendidikan, masalah pendidikan merupakan masalah yang 
cukup penting untuk dicermati, karena seringkali dijadikan barometer dalam melihat tingkat kemajuan suatu daerah. Sementara itu maju mundurnya pendidikan tidak terlepas dari ketersediaan berbagai lembaga pendidikan beserta sarana dan prasarananya. Dari aspek pendidikan enklave Labuhan Haji, sebagian besar memiliki tingkat pendidikan sekolah menengah, Selanjutnya enklave Pelangan sebagian besar memiliki tingkat pendidikan sekolah dasar. Kesadaran pentingnya pendidikan yang dilakukan orang tua terhadap anaknya untuk menuntut ilmu yang lebih tinggi menyebabkan terjadinya pergeseran bahasa pada segmen muda. Hal ini disebabkan segmen muda tidak hanya bergaul dengan satu etnis saja melainkan dengan berbagai etnis. Pergaulan yang dilakukan dengan melibatkan berbagai etnis ini menimbulkan penggunaan berbagai macam bahasa, selanjutnya (3) aspek sosial kemasyarakatan, berhubungan dengan organisasi kemasyarakatan pada setiap daerah pengamatan dengan melibatkan berbagai suku yang berada di wilayah tersebut. Keterlibatan berbagai suku ini menimbulkan berbagai perbedaan bahasa yang harus disikapi secara bijak oleh masyarakat itu sendiri sehingga dapat terjalin hubungan yang harmoni antar sesama tau berlainan suku. Organisasi sosial kemasyarakatan yang dimaksud antara lain seperti adanya LKMD, PKK, karang taruna, dan pengajian ibu-ibu. Dalam kegiatan organisasi kemasyarakatan yang berada di wilayah Labuhan Haji maupun Pelangan dihadiri berbagai suku yang lebih cenderung menggunakan bahasa Sasak dan Indonesia. Penggunaan bahasa tersebut didorong oleh rasa ikut memiliki wilayah ini meskipun mereka bukan penduduk asli tetapi mereka telah menetap dan dibesarkan di wilayah ini, dan agar lebih mudah untuk berkomunikasi, (4) aspek kebutuhan, dari hasil wawancara diketahui, alasan utama suku 
pendatang mempelajari bahasa daerah suku asli adalah untuk memudahkan komunikasi dan interaksi serta menambah pengetahuan terhadap bahasa tersebut. Selanjutnya mereka juga beranggapan bahwa sebagai pendatang harus pandai-pandai untuk menyesuaikan diri. Adanya suatu pemikiran bahwa ketika dia tinggal di suatu wilayah maka seolah menitipkan diri di wilayah tersebut, (5) aspek usia, merupakan salah satu faktor sosial yang membagi dan membedakan kelompok-kelompok manusia dalam masyarakat. Menurut Hidayat, 2007:18-19, menjelaskan bahwa kelompok manusia yang dibedakan menurut usia ini akan memungkinkan munculnya dialek sosial (ragam bahasa menurut faktor sosial) yang sedikit banyak menjadi ciri khas kelompok tersebut. Bahasa anak-anak akan berbeda dengan bahasa remaja. Begitu juga bahasa remaja akan berbeda dengan bahasa orang dewasa dan bahasa orang dewasapun akan berbeda dengan bahasa orang tua. Masing-masing kelompok usia akan memiliki ciri bahasa sendiri-sendiri. Bahasa anakanak menurut hasil penelitian Roger Brown (dalam Sumarsono, 2002: 136) memiliki ciri-ciri antara lain pemyusutan (reduksi) khususnya pada golongan fungtor atau kata tugas seperti kata depan, kata sambung, partikel, dan lain sebagainya. Secara universal bahasa anak dilihat dari segi fonologi mudah menyerap dan memproduksi bunyi-bunyi bilabial pada awal belajar bertuturnya. Selanjutnya bahasa remaja memiliki sifat yang variatif, esklusif, aggresif, dan inovatif. Kita banyak mengenal bahasa eskelusif anak muda seperti bahasa prokem dan bahasa gaul, atau bahasa rahasia lainnya yang tidak diketahui oleh orang lain atau kelompok lain, bahkan kedua orang tua mereka. Inovasi yang dilakukan oleh bahasa remaja dianataranya dengan pelesapan, penggantian, dan 
penambahan, atau dengan memaknai singkata-singkatan umum dengan makna atau kepanjangan baru versi mereka. Dengan demikian bahasa remaja merupakan bahasa yang dinamis. Ia berkembang kapanpun sesuai dengan perkembangan lingkungan dan kebutuhan kelompok mereka. Di lain pihak bahasa orang tua terbukti lebih terbuka, apresiatif, akomodatif, protektif (penuh nasehat), dan konservatif. Terbuka dalam arti tidak mengesklusifkan diri dengan menciptakan bahasa-bahasa khusus supaya berbeda dengan kelompok bahasa orang tua yang lain. Akomodatif dan apresiatif bermakna tidak banyak melakukan pemberontakan secara linguistik dengan melawan bentuk-bentuk baru dan menciptakan bentukbentuk tandingan. Bahasa mereka, seperti umumnya sifat mereka, lebih banyak nerimo (menerima) dan lebih arif atau bijaksana dibandingkan dengan bahasa remaja, dan konservatif dalam makna yang statis, yaitu tidak melakukan pembaruan sesuai dengan perkembangan dan kebutuhan lingkungan mereka. Dari pernyataan di atas maka jelaslah mengapa bahasa yang digunakan oleh segmen sosial muda baik pada komunitas tutur Bugis Haji maupun komunitas tutur Bugis Pelangan memiliki kretaria dominan terpengaruh oleh bahasa Sasak sebagai bahasa suku asli di Pulau Lombok.

Sementara itu bila berbicara mengenai faktor budaya menurut informasi dari informan, salah satu tradisi yang lebih sederhana dapat terlihat dari tradisi pernikahan yaitu bila terjadi pernikahan antara salah seorang warga suku Bugis dengan warga suku lain seperti suku Sasak, maka prosesnya tidak serumit jika terjadi pernikahan antar sesama suku dan begitu pula sebaliknya. Oleh karena itulah maka suku Bugis mencoba untuk beradaptasi dengan mempelajari bahasa khususnya 
bahasa Sasak sebagai bahasa suku asli yang mayoritas di Pulau Lombok ini sehingga dapat menjalin interaksi dengan baik dan dinamis.

\subsection{Simpulan}

Sehubungan dengan uraian di atas akan dikemukakan beberapa hal sebagai hasil kesimpulan dari penelitian kontak bahasa antara komunitas tutur bahasa Bugis dengan komunitas tutur bahasa Sasak. Penelitian bahasa Bugis ini dilakukan pada 2 daerah pengamatan yaitu Desa Labuhan Haji, Desa Pelangan. Pemilihan kedua daerah pengamatan ini berdasarkan hasil penelitian terdahulu bahwa kedua desa ini merupakan desa yang berbeda dialek.

Adaptasi sosial melahirkan adaptasi linguistik di mana masyarakat tutur bahasa Bugis sebagai komunitas pendatang di wilayah itu dapat menyesuaikan diri dengan masyarakat tutur bahasa Sasak sebagai suku asli Pulau Penyesuaian diri ini diwujudkan dalam kehidupan sosial dan kemasyarakatan untuk membangun desa dan membentuk organisasi pedesaan secara bersama-sama.

Adaptasi linguistik yang dilakukan oleh komunitas tutur bahasa Bugis terhadap bahasa Sasak hanya ditemukan dalam bentuk serapan fonologi, dan serapan leksikon.

Kecenderungan dari adaptasi linguistik yang terkait dengan kuatkurangnya pengaruh bahasa Sasak terhadap bahasa Bugis pada enklave Haji dan enklave Pelangan berkategori dominan. Sedangkan pengaruh bahasa Bugis terhadap bahasa Sasak pada enklave Haji dan enklave Pelangan termasuk dalam kreteria kurang. 
Penggunaan bahasa Indonesia dalam masyarakat tutur bahasa Bugis terjadi akibat adanya alih kode dan campur kode. Hal ini biasanya terjadi pada masyarakat tutur bahasa Bugis dan bahasa Sasak bila dalam berkomunikasi tidak seutuhnya faham akan bahasa yang mereka gunakan selain itu bila sesama suku Bugis sedang berbicara dan tiba-tibadatang teman dari suku Sasak, maka secara otomatis mereka akan beralih kode dengan bahasa Indonesia. Hal tersebut dilakukan untuk saling menghargai.

Kecenderungan adaptasi linguistik yang terkait dengan kuatkurangnya pengaruh-memengaruhi antara bahasa Sasak dan bahasa Bugis pada segmen sosial tua maupun muda. Pengaruh bahasa Sasak dan bahasa Indonesia terhadap bahasa Bugis pada segmen sosial muda pada enklave Haji maupun Pelangan termasuk dalam kreteria dominan, sedangkan segmen sosial tua pada kedua enklave diatas termasuk dalam kreteria kurang dominan. Selanjutnya kecenderungan pengaruh bahasa Bugis dan bahasa Indonesia terhadap bahasa Sasak menunjukkan segmen sosial muda pada semua enklave termasuk dalam kreteria dominan, sedangkan segmen sosial tua pada semua enklave juga termasuk dalam kreteria dominan.

Terjadinya pengaruh bahasa yang dominan dan bervariasi ini disebabkan oleh berbagai faktor antara lain geografi, sosial (ekonomi, pendidikan, kebutuhan, usia) dan budaya pada setiap daerah pengamatan yang berbeda. 


\section{DAFTAR PUSTAKA}

Abas, H. 1983. "Fungsionalisasi Bahasa Sebagai Norma Suprasional dan Bahasa Komunikasi Luas : Satuan Perspektif Sosiolinguistik untuk Tahun 2000-an”. Ujung Pandang : Universitas Hasanudin

Burhanuddin, dkk. 2005. Kontak Bahasa Antara Bahasa Sumbawa di Lombok Timur Dengan Bahasa Sasak. Mataram: Kantor Bahasa Provinsi Nusa Tenggara Barat.

Bloomfield, Leonard. 1995. Bahasa (Language). Jakarta: Gramedia Pustaka Utama.

Badan Pusat Statistik Kabupaten Lombok Barat. 2005. "Kecamatan Sekotong Tengah dalam Angka Tahun 2005".

Badan Pusat Statistik Kabupaten Lombok Timur. 2005. "Kecamatan Labuhan Haji dalam Angka Tahun 2005".

Bartholomew, Jhon Ryan. 2001. Alif Lam Mim Kearifan Masyarakat Sasak. PT Tiara Wacana Yogya

Chaer, Abdul dan Leoni Agustina. 1995, Sosiolinguistik: Suatu Pengantar, Jakarta, Rineka Cipta

Damhujin. 2006, "Distribusi dan Pemetaan Varian-varian Bahasa Bugis di Kabupaten Bima dan Dompu (Suatu Kajian Dialektologi)". Mataram: Kantor Bahasa Nusa Tenggara Barat.

Hidayat, Toni Samsul. 2007, "Kontak Bahasa Antara Komunitas Tutur Bahasa Sasak dan Komunitas Tutur Bahasa Sumbawa”. 
Kaseng, Sjaruddin, et al. 1974. Valenssi Morfologi Dasar Kata Kerja Bahasa Bugis Soppeng.

,et al. 1982. Kata Tugas dalam Bahasa Bugis , et al. 1983. Sistem Perulangan Bahasa Bugis

Mahsun. 1994. "Penelitian Dialek geografis Bahasa Sumbawa". Yogyakarta: Disertasi untuk Doktor UGM.

. 1995. Dialektologi Diakronis: Sebuah Pengantar. Yogyakarta: Gadjah Mada University Prees.

. 2005. Metode Penelitian Bahasa:Tahapan Strategi, Metode, dan Tekniknya. Jakarta: PT Raja Grafindo Persada.

. 2006. Bahasa dan Relasi Sosial: Telaah Kesepadanan Adaptasi Linguistik dengan Adaptasi Sosial. Yogyakarta: Gama Media.

Rahardi, Kunjana. 2001. "Sosiolinguistik, Kode dan Alih Kode".Yogyakarta: Pustaka Pelajar.

Rachmawati, Desi. 2006. "Distribusi dan Pemetaan Varian-varian Bahasa Bugis di Pulau Lombok". Mataram: Kantor Bahasa Nusa Tenggara Barat.

Sudaryanto. 1988. Metode linguistik, Metode dan Aneka Teknik Pengumpulan Data. Yogyakarta: Gadjah mada University Press.

Sikki, Muhammad, et al. 1985/1986. Morfologi Kata Benda Bahasa Bugis: Proyek Penelitian Bahasa dan Sastra Indonesia dan Daerah Sulawesi Selatan

, et al. 1986/1987. Morfologi Adjektiva Bahasa Bugis: Proyek Penelitian Bahasa dan Sastra Indonesia dan Daerah Sulawesi Selatan

Sumarsono. 2002. Sosiolinguistik. Yogyakarta: Sabda.

Soekanto, Soerjono, 2005. Sosiologi Suatu pengantar. Jakarta: Raja Grafindo Persada. 
Safarudin, Balok. 2006 Distribusi dan Pemetaan Jenis-Jenis Karya Sastra yang Tumbuh dan Berkembang Pada Masyarakat Tutur Bahasa Bugis di Pulau Lombok. Mataram: Kantor Bahasa Nusa Tenggara Barat. 